\title{
Synthesis of New Energetic Materials and Ionic Liquids Derived from Metronidazole
}

\author{
Miguel A. Romero \\ Executive Committee Deputy of Industrial Affairs, Mexican Chemical Society, Barranca del Muerto No. 26, \\ Colonia Crédito Constructor, Delegación Benito Juárez, 03940 Mexico City, DF, Mexico
}

Correspondence should be addressed to Miguel A. Romero; drmiguelromero@yahoo.ca

Received 25 October 2015; Accepted 16 December 2015

Academic Editor: Kirpal Bisht

Copyright (C) 2016 Miguel A. Romero. This is an open access article distributed under the Creative Commons Attribution License, which permits unrestricted use, distribution, and reproduction in any medium, provided the original work is properly cited.

\begin{abstract}
Simple and efficient synthetic procedures were established for the preparation of new energetic covalent compounds, salts, and protonated ionic liquids based on the readily available antimicrobial agent metronidazole. Some of these materials exhibit the desirable properties of energetic materials and energetic ionic liquids, such as low vapor pressure, low melting point, good chemical and thermal stability, and high energetic content. For each of the relevant compounds prepared, thermal stability was determined by differential scanning calorimetry. Some of these compounds may be considered promising precursors of pharmaceuticals such as antimicrobial, antiparasitic, antifungal, antineoplastic agents, or enzyme inhibitors.
\end{abstract}

\section{Introduction}

Interest in energetic ionic liquids (EILs) has grown exponentially in the last few years as a result of their application in various areas of research such as electrochemistry, separation science, chemical synthesis, and catalysis $[1,2]$. Research in the field of ionic liquids as energetic materials (EMs) is becoming quite important because they are easy to manufacture and generally stable (and thus safer to transport than conventional EMs) and because their physicochemical characteristics render them suitable for diverse applications $[3,4]$. The main thrust for the development of new EILs has been their substitution as propellants for such compounds as hydrazine and derivatives thereof, which at present pose various problems such as corrosion, safety in handling and storage, high melting points, and the need to use plasticizers [5]. However, the use of some EILs as additives, plasticizers, main charges, or even pharmacological agents [6] presents a wide array of possibilities for further development. One area of development of new EILs is the use of imidazole-based compounds for the preparation of salts, either protonated or alkylated, that exhibit the physical and chemical properties typical of energetic materials [7-13].

\section{Experimental Section}

\subsection{General Information}

Caution! Even though the handling of the reported compounds presented no problems under normal laboratory conditions, one must exercise extreme caution and employ standard precautionary measures at all stages of the synthesis, handling, storage, and disposal of EMs. The use of suitable protective gear and equipment is required and strongly encouraged.

Note. All reactions were carried out under normal air atmosphere using oven dried glassware. All chemicals were used as received unless otherwise noted. Reaction solvents were dried by distillation from the appropriate drying agent and stored over $3 \AA$ molecular sieves as required. The term brine is used to describe a saturated aqueous solution of sodium chloride.

Infrared spectra were recorded directly as liquids or solids (both referred to as "neat") on a Cary 660 Series FTIR Spectrometer with internal calibration. Only the strongest diagnostic bands are reported. Proton and carbon nuclear magnetic resonance $\left({ }^{1} \mathrm{H}\right.$ NMR and ${ }^{13} \mathrm{C}$ NMR $)$ spectra were 
recorded on a Bruker AVANCE-III 500 (500 MHz) spectrometer. Unless otherwise stated, $\mathrm{CDCl}_{3}$ was used as solvent. Elemental analyses were performed on a Perkin Elmer PE2400 elemental analyzer by the USAI-UNAM microanalytical laboratory. Melting points were measured on a Mettler Toledo DSC1 (STAR 11.0) DSC apparatus; decomposition temperature $\left(T_{d}\right)$, glass transition $\left(T_{g}\right)$, and DSC plots were also recorded on this system. $T_{d}$ and $T_{g}$ temperatures are given in Celsius degrees and refer to onset, not to peak temperatures (except for compound 4 where peak temperatures are reported). Heating rate for DSC runs is either $5^{\circ}$ or $10^{\circ} \mathrm{C} \mathrm{min}^{-1}$, as specified in the experimental details. DSC run for compound 4 was carried out on a NETZSCH STA 449F3 instrument. Gas chromatography/mass spectroscopy analyses were carried out on Agilent Technologies $6890 \mathrm{~N}$ Network GC System. Thin layer chromatography (TLC) was carried out on commercial aluminum backed silica gel 60 plates (E. Merck, type 5554, $0.2 \mathrm{~mm}$ ). Visualization was accomplished with UV light $(254 \mathrm{~nm})$, iodine, and/or heating the chromatograms after staining with a solution of phosphomolybdic acid (PMA) in ethanol (20\% w/v, Aldrich), a solution of ammonium molybdate and cerium sulfate in $10 \%$ sulfuric acid $(5 \% \mathrm{w} / \mathrm{v}$ ammonium molybdate and $\left.0.1 \% \mathrm{w} / \mathrm{Ce}(\mathrm{SO})_{4}\right)$, or a solution of p-anisaldehyde in a sulfuric acid-EtOH mixture (5\% v/v anisaldehyde and 5\% v/v sulfuric acid). Flash chromatography was performed on 230-400 mesh silica gel (Siliaflash 60 Silica Gel). The reported eluent solvent solution ratios are volume to volume ratios. The terms in vacuo or "under reduced pressure" are used to describe removal of solvent using a rotary evaporator.

\subsection{Compound Preparation}

2.2.1. Synthesis of 2-(2-Methyl-5-nitro-1H-imidazol-1-yl)ethyl Nitrate (2). Ammonium nitrate $(1.90 \mathrm{~g}, 0.237 \mathrm{~mol})$ is added to a cold (ice-water bath) nitric acid solution $(68 \%, 16.03 \mathrm{~g}$, and $0.16 \mathrm{~mol})$, while stirring. Then sulfuric acid $(97 \%, 27.78 \mathrm{~g}$, and $0.276 \mathrm{~mol}$ ) is added slowly and the mixture is stirred for $5 \mathrm{~min}$, followed by the portionwise addition of metronidazole $(3 \mathrm{~g}, 17.528 \mathrm{mmol})$. The reaction mixture is then warmed to room temperature and is stirred for $30 \mathrm{~min}$ and then the contents of the reaction mixture are transferred to a separation (or addition) funnel. This mixture is added dropwise to a stirred ice-water mixture (200 g crushed ice; $100 \mathrm{~mL}$ water) while at the same time adding, also dropwise, a solution of sodium hydroxide $(28.48 \mathrm{~g}, 0.712 \mathrm{~mol})$ at approximately the same rate. After the addition the empty reaction container and its corresponding funnel are rinsed into the ice-water mixture. The $\mathrm{pH}$ is finally adjusted to neutral with the addition of a saturated solution of sodium bicarbonate or $10 \% \mathrm{HCl}$ solution, as required. The resulting mixture is extracted with $\mathrm{CH}_{2} \mathrm{Cl}_{2}(3 \times 150 \mathrm{~mL})$ and the combined organic fractions are then washed with brine and dried with anhydrous sodium sulfate. After reduced pressure removal of the solvent the residual material is crystallized with a hexaneethyl acetate mixture to give solid compound 2 (3.26 g, 86\% yield) as fine white needles, exhibiting oxygen balance $\Omega=$ $-81.4 \%$; DSC (heating rate: $5^{\circ} \mathrm{C} \mathrm{min}^{-1}$ ): $\mathrm{mp}=70.5^{\circ} \mathrm{C} ; T_{d}=$ $182.9^{\circ} \mathrm{C}$; IR (neat) $\nu_{\max }: 3127,3018,2983,2900,1632,1451,1424$, $1358,1267,1254,1184,888,852,821$, and $707 \mathrm{~cm}^{-1} ;{ }^{1} \mathrm{H}$ NMR $\left(\mathrm{CDCl}_{3}, 500 \mathrm{MHz}\right) \delta 7.96(\mathrm{~s}, 1 \mathrm{H}), 4.84(\mathrm{t}, J=5 \mathrm{~Hz}, 2 \mathrm{H}), 4.66$ $(\mathrm{t}, J=5 \mathrm{~Hz}, 2 \mathrm{H})$, and $2.51(\mathrm{~s}, 3 \mathrm{H}) \mathrm{ppm} ;{ }^{13} \mathrm{C} \mathrm{NMR}\left(\mathrm{CDCl}_{3}\right.$, $125 \mathrm{MHz}) \delta 150.9,138.4,133.5,70.4$, 43.6, and 14.2 ppm; GCMS $(\mathrm{m} / z): 171,154,124,81$, and 53 amu. Anal. C 33.47\%, H 3.53\%, and $\mathrm{N} 25.83 \%$; calcd for $\mathrm{C}_{6} \mathrm{H}_{8} \mathrm{~N}_{4} \mathrm{O}_{5}, \mathrm{C} 33.34 \%, \mathrm{H} 3.73 \%$, and N $25.92 \%$.

2.2.2. Synthesis of 2-Methyl-5-nitro-1-[2-(nitrooxy)ethyl]-1Himidazol-3-ium Nitrate (4). A solution of nitric acid in $\mathrm{CH}_{2} \mathrm{Cl}_{2}(3.1 \mathrm{~mL}, 1.53 \mathrm{M})$ is added dropwise to a stirred solution of compound $2(0.98 \mathrm{~g}, 4.626 \mathrm{mmol})$ in $\mathrm{CH}_{2} \mathrm{Cl}_{2}(30 \mathrm{~mL})$ at room temperature. The reaction mixture is stirred for $10 \mathrm{~min}$, during which a dense oily phase is distinguished apart from the $\mathrm{CH}_{2} \mathrm{Cl}_{2}$ solution. The supernatant phase is removed by decantation and a successive series of eight thorough washings with $5 \mathrm{~mL}$ portions of $\mathrm{CH}_{2} \mathrm{Cl}_{2}$ is carried out. The remaining solvent is eliminated under reduced pressure, and the resulting oil is subjected to column chromatography on silica gel (ethyl acetate-methanol $15: 1$ ) to yield compound 4 $(1.252 \mathrm{~g}, 99 \%)$ as a colorless oil exhibiting oxygen deficiency $\Omega=-48.7 \%$; DSC (heating rate: $10^{\circ} \mathrm{C} \mathrm{min}^{-1}$ ): $T 1_{d}=168.3^{\circ} \mathrm{C}$, $T 2_{d}=175.3^{\circ} \mathrm{C}$, and $T 3_{d}=208.7^{\circ} \mathrm{C}$ (all peak temperatures); soluble in acetone and methanol; insoluble in $\mathrm{CH}_{2} \mathrm{Cl}_{2}$, AcOEt, and hexane; IR (neat) $v_{\max } 3401,3138,2907,1636$, $1540,1505,1372,1313,1279,1193,887$, and $828 \mathrm{~cm}^{-1} ;{ }^{1} \mathrm{H}$ NMR $\left(\mathrm{CD}_{3} \mathrm{OD}, 500 \mathrm{MHz}\right) \delta 8.64(\mathrm{~s}, 1 \mathrm{H}), 5.45$ (br s, $\left.1 \mathrm{H}\right), 5.04-4.97$ (m, $4 \mathrm{H})$, and $2.83(\mathrm{~s}, 3 \mathrm{H}) \mathrm{ppm} ;{ }^{13} \mathrm{C} \mathrm{NMR}\left(\mathrm{CD}^{3} \mathrm{OD}, 125 \mathrm{MHz}\right)$ $\delta$ 149.7, 131.5, 123.2, 70.1, 44.7, and $11.1 \mathrm{ppm}$. Anal. C 26.23\%, $\mathrm{H} 3.59 \%$, and $\mathrm{N} 23.78 \%$; calcd for $\mathrm{C}_{6} \mathrm{H}_{9} \mathrm{~N}_{5} \mathrm{O}_{8}$ : C $25.81 \%, \mathrm{H}$ $3.25 \%$, and N 25.09\%.

2.2.3. Synthesis of 2-Methyl-5-nitro-1-[2-(nitrooxy)ethyl]-1Himidazol-3-ium Picrate (5). Picric acid (0.243 g, $1.061 \mathrm{mmol}$ ) is dissolved in a stirred mixture of $\mathrm{CH}_{2} \mathrm{Cl}_{2}(3 \mathrm{~mL})$ and $\mathrm{Et}_{2} \mathrm{O}$ $(4 \mathrm{~mL})$, to which nitrate ester $2(0.230 \mathrm{~g}, 1.064 \mathrm{mmol})$ is then added dropwise as a solution in $\mathrm{CH}_{2} \mathrm{Cl}_{2} / \mathrm{Et}_{2} \mathrm{O}(2 \mathrm{~mL}$, $1: 1$, while stirring vigorously. The reaction mixture is then subjected to separation of the resulting bright yellow precipitate by means of a centrifuge ( $4000 \mathrm{rpm}, 2 \mathrm{~min})$, discarding the supernatant solution. The solid is then washed and centrifuged three times with a $\mathrm{Et}_{2} \mathrm{O} / \mathrm{CH}_{2} \mathrm{Cl}_{2}$ solution $(1 \mathrm{~mL}$ each washing, $5: 2$ ), finally eliminating the remaining solvent under high vacuum (90 Torr), to give picrate 5 (0.392 g, $83 \%$ yield) as a bright yellow powder. DSC (heating rate:

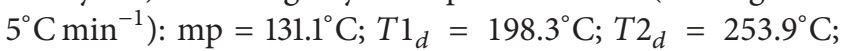
IR (neat) $v_{\max } 3728,3707,3163,2973,2361\left(\mathrm{~s}, \mathrm{CO}_{2}\right), 2338(\mathrm{~s}$, $\left.\mathrm{CO}_{2}\right), 1541,1493,1317,1267,882,844$, and $705 \mathrm{~cm}^{-1} ;{ }^{1} \mathrm{H}$ NMR (acetone-d6, $500 \mathrm{MHz}) \delta 8.92(\mathrm{~s}, 2 \mathrm{H}), 8.41(\mathrm{~s}, 1 \mathrm{H}), 8.08(\mathrm{br}$ $\mathrm{s}, 1 \mathrm{H}), 5.18-5.07(\mathrm{~m}, 4 \mathrm{H})$, and $2.89(\mathrm{~s}, 3 \mathrm{H}) \mathrm{ppm} ;{ }^{13} \mathrm{C} \mathrm{NMR}$ (acetone-d6, $125 \mathrm{MHz}$ ) $\delta 157.8,150.6,140.3,138.8,132.0,126.3$, $125.5,70.8,44.1$, and $12.2 \mathrm{ppm}$. Anal. C $32.78 \%, \mathrm{H} 1.93 \%$, and $\mathrm{N} 21.49 \%$; calcd for $\mathrm{C}_{12} \mathrm{H}_{11} \mathrm{~N}_{7} \mathrm{O}_{12}$ : C $32.37 \%, \mathrm{H} 2.49 \%$, and $\mathrm{N}$ $22.02 \%$.

2.2.4. Synthesis of 1-(2-Azidoethyl)-2-methyl-5-nitro-1H-imidazole (3). To a cooled $\left(0^{\circ} \mathrm{C}\right)$ solution of triphenylphosphine 
(8.43 g, $32.14 \mathrm{mmol})$ in $\mathrm{CH}_{2} \mathrm{Cl}_{2}(100 \mathrm{~mL})$ bromine is slowly added $(1.65 \mathrm{~mL}, 32.20 \mathrm{mmol})$ followed by addition of triethylamine $(4.48 \mathrm{~mL}, 32.14 \mathrm{mmol})$. To the resulting solution metronidazole is then added in small portions $(5.00 \mathrm{~g}$, $29.21 \mathrm{mmol}$ ), while stirring. After $5 \mathrm{~min}$ the reaction mixture is warmed to room temperature, stirred for further $30 \mathrm{~min}$, and then quenched with water $(150 \mathrm{~mL})$ and a saturated solution of aqueous sodium thiosulphate $(10 \mathrm{~mL})$. The mixture is then extracted with $\mathrm{CH}_{2} \mathrm{Cl}_{2}(3 \times 50 \mathrm{~mL})$ and the combined extracts are washed with brine $(1 \times 50 \mathrm{~mL})$ and dried with anhydrous sodium sulfate. The resulting solution is then percolated through a short silica gel column after which the solvent is removed in vacuo. To the crude mass $\mathrm{Et}_{2} \mathrm{O}(50 \mathrm{~mL})$ is then added and ground with a flat end glass rod, decanting the supernatant solution and repeating the process two more times. The combined washings are then filtered again through a short silica gel column, the solvent from the collected fraction is then removed, and the resulting oil (bromide) is then subjected to high vacuum (90 Torr) for $10 \mathrm{~min}$. The oil is then dissolved in DMF $(30 \mathrm{~mL})$ and sodium azide $(3.80 \mathrm{~g}, 58.45 \mathrm{mmol})$ is added in small portions while stirring. The reaction mixture is then warmed up to $60^{\circ} \mathrm{C}$ and stirred for $22 \mathrm{~h}$, followed by cooling to room temperature. Reaction workup is then done by adding water $(150 \mathrm{~mL})$ and extracting the mixture with AcOEt $(3 \times 50 \mathrm{~mL})$, washing with water $(2 \times 50 \mathrm{~mL})$, brine $(1 \times 50 \mathrm{~mL})$, and drying the collected organic portions with anhydrous sodium sulphate. The solvent is then removed in vacuo and the crude oil is subjected to column chromatography on silica gel (eluting initially with hexane/AcOEt $1: 1$ and gradually decreasing the eluting solution ratio to $1: 9)$. The solvent is then removed in vacuo from the collected column fractions to give azide 3 (3.79 g, 66\% yield from metronidazole), exhibiting oxygen balance $\Omega=-114.2 \%$; DSC (heating rate: $10^{\circ} \mathrm{C} \mathrm{min}^{-1}$ ): $\mathrm{mp}$ $=55.1^{\circ} \mathrm{C}\left(\right.$ Lit. $\left.53-54^{\circ} \mathrm{C}\right), T_{g}=87.7^{\circ} \mathrm{C}$, and $T_{\mathrm{dec}}=222.0^{\circ} \mathrm{C}$; GCMS $196\left(\mathrm{M}^{+}\right), 151,122(100), 95,80$, and $50 \mathrm{amu}$; IR (neat) $v_{\max } 3127,2933,2868,2096$ (s), 1527, 1462, 1424, 1360, 1260, $1184,1147,823$, and $742 \mathrm{~cm}^{-1} ;{ }^{1} \mathrm{H}$ NMR $\left(\mathrm{CDCl}_{3}, 500 \mathrm{MHz}\right)$ $\delta 7.94(\mathrm{~s}, 1 \mathrm{H}), 4.42(\mathrm{t}, J=5 \mathrm{~Hz}, 2 \mathrm{H}), 3.76(\mathrm{t}, J=5 \mathrm{~Hz}, 2 \mathrm{H})$, $2.52(\mathrm{~s}, 3 \mathrm{H}) \mathrm{ppm} ;{ }^{13} \mathrm{C} \mathrm{NMR}\left(\mathrm{CDCl}_{3}, 125 \mathrm{MHz}\right) \delta 151.4,138.2$, 133.4, 50.9, 45.5, and 14.4 ppm; Anal. C 37.24\%, H 3.68\%, and $\mathrm{N} 40.82 \%$; calcd for $\mathrm{C}_{6} \mathrm{H}_{8} \mathrm{~N}_{6} \mathrm{O}_{2}$ : C $36.74 \%, \mathrm{H} 4.11 \%$, and $\mathrm{N}$ $42.84 \%$.

2.2.5. Synthesis of 1-(2-Azidoethyl)-2-methyl-5-nitro-1H-imidazol-3-ium Nitrate (6). Azide 3 (2.74 g, $13.968 \mathrm{mmol})$ is dissolved in $\mathrm{CH}_{2} \mathrm{Cl}_{2}(25 \mathrm{~mL})$, the solution is cooled to $0^{\circ} \mathrm{C}$, and to this stirred solution a $6.55 \mathrm{M}$ solution of $\mathrm{HNO}_{3}$ is then added dropwise in $\mathrm{CH}_{2} \mathrm{Cl}_{2}(2.13 \mathrm{~mL}, 1$ equiv.). After the addition the solution is warmed up to room temperature and stirred for $30 \mathrm{~min}$, after which the solvent is removed in vacuo. The remaining oil is then subjected to Flash column chromatography by dissolving it in the minimum amount of a $\mathrm{CH}_{2} \mathrm{Cl}_{2} / \mathrm{MeOH}$ solution $(5: 1)$ in order to add it to the column. Then the mixture is eluted using initially a $\mathrm{MeOH} / \mathrm{CH}_{2} \mathrm{Cl}_{2} /$ hexane/AcOEt solution (1:18:5:5v, resp.) and increasing gradually the $\mathrm{MeOH}$ content of the eluting solution gradually as the chromatography proceeds. After fraction collection and solvent removal, ionic liquid 6 was obtained as a light yellow-colored oil (3.14 g, 97\% yield), exhibiting oxygen deficiency $\Omega=-71.0 \%$; DSC (heating rate, $\left.10^{\circ} \mathrm{Cmin}{ }^{-1}\right): T_{g}=81.6^{\circ} \mathrm{C}, T 1_{d}=144.0^{\circ} \mathrm{C}$, and $T 2_{d}=$ $225.0^{\circ} \mathrm{C}$; GCMS 196, 151, 122(100), 95, 80, and $53 \mathrm{amu}$; IR (neat) $v_{\max } 3400$ (br), 3225, 3113, 2980, 2101(s), 1614, 1535, $1503,1419,1366,1295,1262,1187,1034,930,825$, and $737 \mathrm{~cm}^{-1}$; ${ }^{1} \mathrm{H}$ NMR (DMSO-d6, $\left.500 \mathrm{MHz}\right) \delta 9.08$ (br s, $\left.1 \mathrm{H}\right), 8.36(\mathrm{~s}$, $1 \mathrm{H}), 4.54(\mathrm{t}, J=5 \mathrm{~Hz}, 2 \mathrm{H}), 3.84(\mathrm{t}, J=5 \mathrm{~Hz}, 2 \mathrm{H})$, and 2.57 (s, 3H) ppm; ${ }^{13} \mathrm{C}$ NMR (DMSO-d6, $\left.125 \mathrm{MHz}\right) \delta 151.0,138.7$, 130.1, 50.4, 46.0, and 13.7 ppm; Anal. C 27.58\%, $\mathrm{H} 4.11 \%$, and

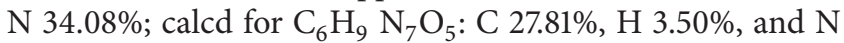
$37.83 \%$.

2.2.6. Synthesis of 1: 1 Mixture of 1-(2-Azidoethyl)-2-methyl-5nitro-1H-imidazole and Picric Acid (7). Picric acid (0.467 g, $2.038 \mathrm{mmol})$ is dissolved in $\mathrm{Et}_{2} \mathrm{O}(25 \mathrm{~mL})$ at room temperature and then immediately added to a stirred solution of azide $3(0.400 \mathrm{~g}, 2.039 \mathrm{mmol})$ also at room temperature. After the addition the mixture is stirred for $15 \mathrm{~min}$ and then filtered. The solid thus obtained is then washed on the filter paper with $\mathrm{Et}_{2} \mathrm{O}(4 \times 5 \mathrm{~mL}$ portions $)$ and then allowed to air dry followed by high vacuum treatment to remove traces of solvent. In this manner mixture 7 (as determined by the DSC behavior of the material) is obtained as a fine (fluffy) yellow solid $(0.785 \mathrm{~g}, 90 \%$ recovery $)$, exhibiting oxygen deficiency $\Omega=$ $-77.2 \%$; DSC (heating rate, $10^{\circ} \mathrm{C} \mathrm{min}^{-1}$ ): $\mathrm{mp}_{1}=124.3^{\circ} \mathrm{C} ; \mathrm{mp}_{2}$ $=135.0^{\circ} \mathrm{C} ; T_{d}=243.2^{\circ} \mathrm{C}$; GCMS 196, 168, 151, 122(100), 95, 80, and $53 \mathrm{amu}$; IR (neat) $v_{\max } 3191,2500$ (br), 2134, 2099, 1601, $1567,1524,1427,1323,1240,1191,1164,916,817$, and $712 \mathrm{~cm}^{-1}$; ${ }^{1} \mathrm{H}$ NMR (DMSO-d6, $\left.500 \mathrm{MHz}\right) \delta 9.76$ (br s, $\left.1 \mathrm{H}\right), 8.60(\mathrm{~s}$, $2 \mathrm{H}), 8.41(\mathrm{~s}, 1 \mathrm{H}), 4.55(\mathrm{t}, J=7.5 \mathrm{~Hz}, 2 \mathrm{H}), 3.86(\mathrm{t}, J=7.5 \mathrm{~Hz}$, $2 \mathrm{H}$ ), and $2.60(\mathrm{~s}, 3 \mathrm{H}) \mathrm{ppm} ;{ }^{13} \mathrm{C}$ NMR (DMSO-d6, $125 \mathrm{MHz}$ ) $\delta$ 161.0, 150.9, 142.2, 138.7, 129.3, 125.6, 125.1, 50.2, 46.0, and 13.6 ppm; Anal. C 34.11\%, H 2.17\%, and N 28.96\%; calcd for $\mathrm{C}_{12} \mathrm{H}_{11} \mathrm{~N}_{9} \mathrm{O}_{9}$ : C $33.89 \%, \mathrm{H} 2.61 \%$, and N 29.64\%.

\section{Results and Discussion}

Herein we report our exploratory work into the transformation of the readily available and inexpensive antimicrobial agent metronidazole (1; Figure 1), a drug considered to be the "gold standard" antibiotic against which all other antibiotics with anaerobic activity may be compared $[14,15]$. The energetic materials in the form of covalent compounds, salts, and protonated ionic liquids (PILs) that were prepared from metronidazole are depicted in Figure 1.

A straightforward procedure for producing PILs is the reaction of a suitable acid with an azo compound to produce a protonated azolium-based salt. It is also possible to produce energetic aprotic ionic liquids wherein the cation is constituted by a fully alkylated quaternary ammonium center. In the present work we favored the simpler PIL pathway to expedite the preparation of a number of nitrate and picrate salts by the direct reaction of $\mathrm{HNO}_{3}$ or picric acid with metronidazole derivatives.

Despite what may seem to be a facile way of producing protonated ILs, it should be noted that there are limitations in 


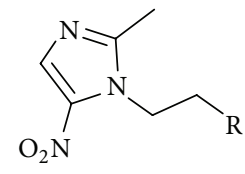

$1 \mathrm{R}=\mathrm{OH}$

$2 \mathrm{R}=\mathrm{ONO}_{2}$

$3 \quad \mathrm{R}=\mathrm{N}_{3}$

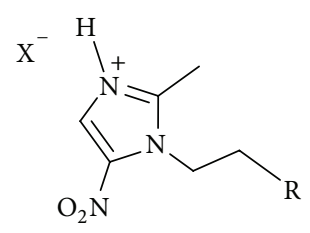

$4 \quad \mathrm{R}=\mathrm{ONO}_{2} \quad \mathrm{X}=\mathrm{NO}_{3}$

$5 \quad \mathrm{R}=\mathrm{ONO}_{2} \quad \mathrm{X}=\mathrm{Pic}$

$6 \quad \mathrm{R}=\mathrm{N}_{3} \quad \mathrm{X}=\mathrm{NO}_{3}$

$\operatorname{Pic}($ picryl $)=\mathrm{O}_{2}$

FIgURE 1: Metronidazole (1) and derived energetic covalent compounds, salts, and ionic liquids.<smiles>Cc1ncc([N+](=O)[O-])n1CCO</smiles>

1

(a)

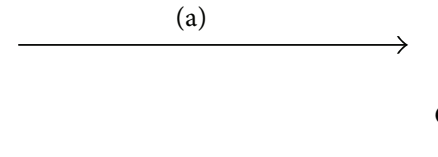<smiles>Cc1ncc([N+](=O)[O-])n1CCO[N+](=O)[O-]</smiles>

2 (86\%)

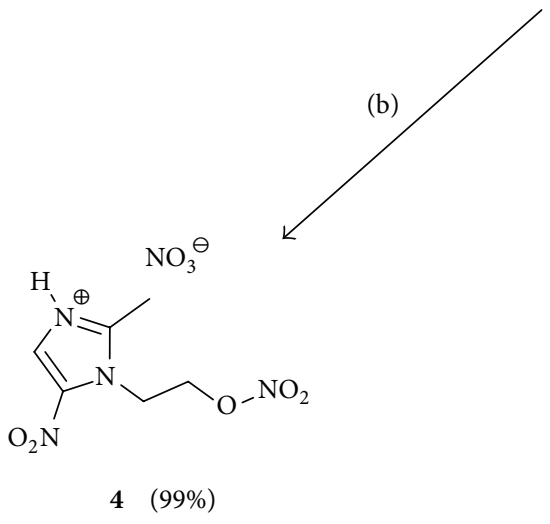

Scheme 1: Preparation of nitrate ester 2, PEIL 4, and salt 5. (a) $\mathrm{HNO}_{3} / \mathrm{H}_{2} \mathrm{SO}_{4} / \mathrm{NH}_{4} \mathrm{NO}_{3}, 0^{\circ} \mathrm{C}$ to r.t., 1 h; (b) $\mathrm{HNO}_{3}, \mathrm{CH}_{2} \mathrm{Cl}_{2}$, r.t.; and (c) picric acid, $\mathrm{CH}_{2} \mathrm{Cl}_{2}-\mathrm{Et}_{2} \mathrm{O}$.

the formation of protonated imidazolium nitrate and picrate salts. Smiglak et al. [16] have demonstrated that when the imidazole nucleus is substituted with two or three nitro functional groups the synthesis of the corresponding 1,3dialkylimidazolium or 1-alkyl protonated cations is futile due to their resistance to $\mathrm{N}$-alkylation or protonation, respectively. Such is the case of 1-methyl-2,4-dinitroimidazole and 1-methyl-4,5-dinitroimidazole [16, 17]. However, metronidazole has only one nitro functional group within the azole nucleus; thus, it was estimated it would be a suitable candidate for forming various energetic protonated ionic liquids (EPILs).
Nitrate ester 2 was initially prepared from metronidazole (1) using a $\mathrm{H}_{2} \mathrm{SO}_{4}-\mathrm{HNO}_{3}-\mathrm{NH}_{4} \mathrm{NO}_{3}$ nitrating mixture in good yield (Scheme 1). Compound $\mathbf{2}$ is a white crystalline (fine needles) solid $\left(\mathrm{mp}=68-70^{\circ} \mathrm{C}\right)$ with oxygen balance $\Omega=-81.4 \%$, maximum calculated density $[18,19] \rho_{\max }=$ $1.63 \mathrm{~g} \mathrm{~cm}^{-3}$, and theoretical detonation velocity (Rothstein \& Petersen method) [20-23] $\mathbf{D}=6534 \pm 131 \mathrm{~ms}^{-1}$, which is comparable to that of high explosives such as TNT $\left(\mathbf{D}=6950 \mathrm{~ms}^{-1}\right.$ @ $\left.1.654 \mathrm{gcm}^{-3}\right)$. This compound exhibited typical IR signals at $3127 \mathrm{~cm}^{-1}$ (imidazole ring C-H) and 1631 and $1424 \mathrm{~cm}^{-1}$ (nitro and nitrate ester functions). In order to assess the thermal stability of all relevant compounds prepared, we 


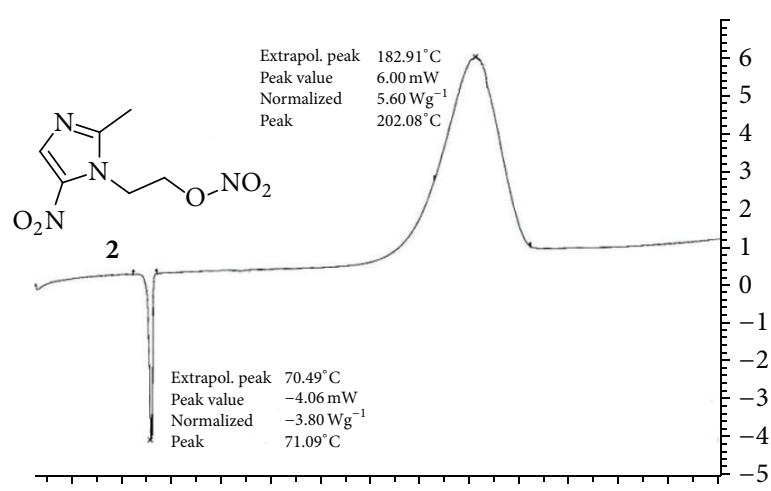

$40 \quad 60 \quad 80 \quad 100120140160180200220240260280$

$\left({ }^{\circ} \mathrm{C}\right)$
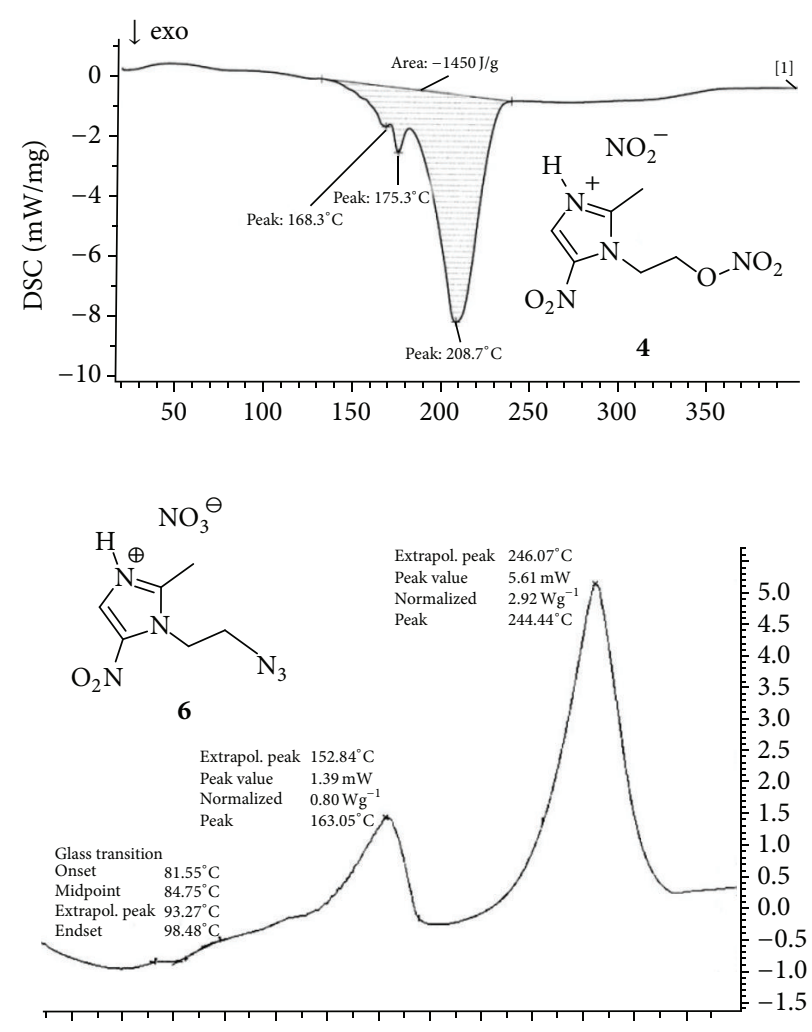

$40 \quad 60 \quad 80 \quad 100120140160180200220240260280$

$\left({ }^{\circ} \mathrm{C}\right)$

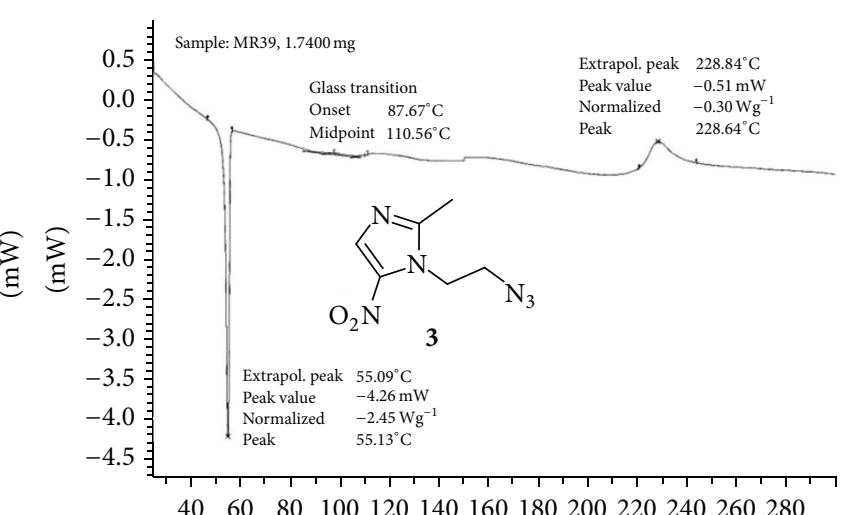

$\left({ }^{\circ} \mathrm{C}\right)$

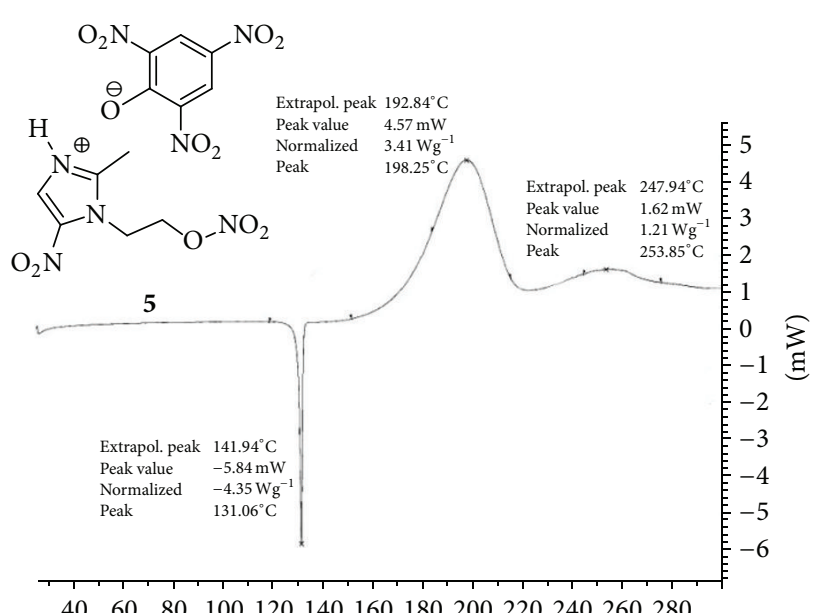

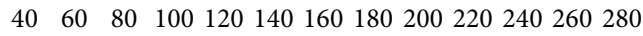

$\left({ }^{\circ} \mathrm{C}\right)$

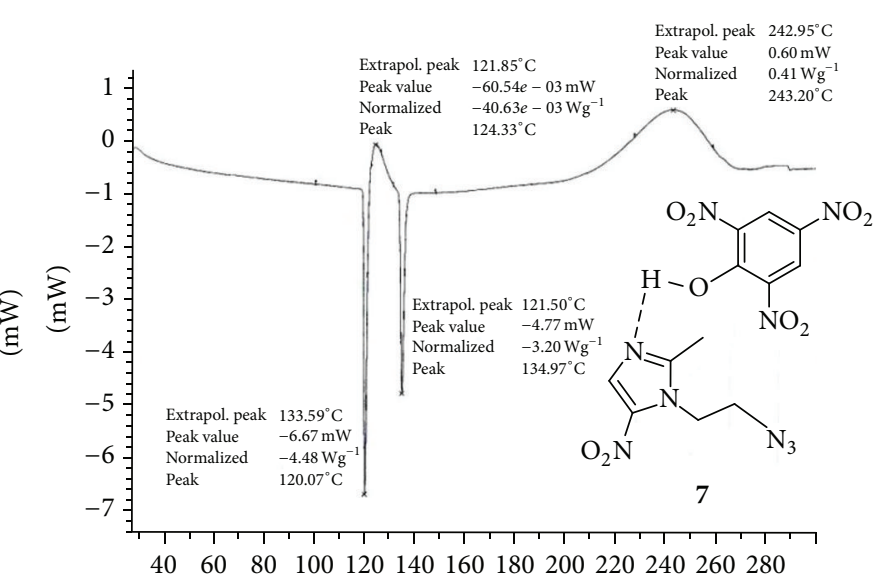

$\left({ }^{\circ} \mathrm{C}\right)$

FIgURE 2: DSC plots of compounds 2, 3, EIL 4, RTEIL 6, salt 5, and mixture 7.

determined their differential scanning calorimetric (DSC) properties (see Figure 2 and Table 1). In the case of compound 2 , its DSC run at a heating rate of $5^{\circ} \mathrm{C} \mathrm{min}^{-1}$ established $\mathrm{mp}=70.5^{\circ} \mathrm{C}$ and a (onset) decomposition temperature $T_{d}=$ $182.9^{\circ} \mathrm{C}$ (Figure 2).

Having compound 2 on hand, a simple acid neutralization with a dichloromethane solution of either concentrated
$\mathrm{HNO}_{3}$ or picric acid furnished protonated energetic ionic liquid (PEIL) 4 as a colorless oil exhibiting a broad signal at $3401 \mathrm{~cm}^{-1}$ on its FTIR spectrum and a broad singlet at $5.45 \mathrm{ppm}$ on its ${ }^{1} \mathrm{H}$ NMR spectrum, both due to the imidazolium proton, or salt 5 , respectively (Scheme 1 ). The DSC runs for these compounds were as follows: $T 1_{d}=$ $168.3^{\circ} \mathrm{C}$ (peak), $T 2_{d}=175.3^{\circ} \mathrm{C}$ (peak), and $T 3_{d}=208.7^{\circ} \mathrm{C}$ 
TABLE 1: Oxygen deficiency and DSC data for compounds 2-6 and mixture 7.

\begin{tabular}{|c|c|c|c|c|}
\hline Compound & Oxygen deficiency $(\Omega), \%$ & Melting point ${ }^{\circ} \mathrm{C}$ & $\begin{array}{l}\text { Decomposition temperature (1st } \\
\text { transition; } T 1_{d},{ }^{\circ} \mathrm{C} \text {; onset) }\end{array}$ & $\begin{array}{c}\text { Decomposition temperature } \\
\text { (2nd transition } T 2_{d} ; 3 \text { rd transition } \\
T 3_{d},{ }^{\circ} \mathrm{C} ; \text { onset) }\end{array}$ \\
\hline 2 & -81.4 & 70.5 & 182.9 & - \\
\hline 3 & -114.2 & 55.1 & $87.7^{\mathrm{a}}$ & $222.0^{\mathrm{b}}$ \\
\hline 4 & -48.7 & - & 168.3 & $175.3 ; 208.7$ \\
\hline 5 & -63.0 & 141.9 & 192.8 & 247.9 \\
\hline 6 & -71.0 & $-^{c}$ & 144.0 & 225.0 \\
\hline $7^{\mathrm{d}}$ & -77.2 & $124.3 ; 135.0^{\mathrm{d}}$ & 243.2 & - \\
\hline
\end{tabular}

(peak) for $4 ; T_{m}=141.9^{\circ} \mathrm{C}, T 1_{d}=198.25^{\circ} \mathrm{C}$ (peak), and $T 2_{d}=253.85^{\circ} \mathrm{C}$ (peak) for 5 (see Figure 2 and Table 1 ). These results follow the expected trend whereby picrate salts of protonated imidazolium cations tend to be thermally more stable than the corresponding nitrate salts [16]. Compound 4 turned out to be rather unstable. It is very sensitive to traces of water and acid and tends to revert to metronidazole and nitric acid. Depending on the degree of contamination by acid or even atmospheric humidity one may observe cloudiness in a matter of a few hours at room temperature and even precipitated metronidazole upon storage at $0^{\circ} \mathrm{C}$ after a few days. A TG scan showed that in the range from 20 to $115^{\circ} \mathrm{C}$ there is already a mass deficit of $8.49 \%$. More stable samples can be obtained performing a flash silica gel column chromatography eluting with ethyl acetate-methanol $15: 1$ right after workup. It is presumed that internal protonation by the protic ammonium moiety facilitates nitrate ester hydrolysis, thus reversibly yielding back the starting materials. In contrast compounds $\mathbf{5}$ and $\mathbf{6}$ exhibit stability under ordinary atmospheric conditions and good shelf-life (several months at $0^{\circ} \mathrm{C}$ so far). The IR spectra of compound 5 show strong $\mathrm{CO}_{2}$ absorptions in the $2350 \mathrm{~cm}^{-1}$ region (see Section 2); this exemplifies the known property of some ionic liquids to strongly scavenge $\mathrm{CO}_{2}[24,25]$. This property of some ILs has received much attention given the climate impact of the growing $\mathrm{CO}_{2}$ atmospheric concentration, and there is currently much interest in developing ILs aimed at eliminating anthropogenic carbon emissions [26].

The hydroxyethylene moiety attached to position 1 on the imidazole nucleus of metronidazole should allow for versatile transformations. Thus, we next considered the replacement of the primary alcohol functional group with an azide functional group. This was accomplished initially transforming the primary alcohol into its corresponding bromide, followed by nucleophilic substitution using sodium azide in DMF to give azide 3 (Scheme 2). This compound was previously prepared by Levon from metronidazole mesylate $[27,28]$ but was only partially characterized. Compound 3, a white crystalline solid, exhibited a characteristic FTIR strong signal at $2096 \mathrm{~cm}^{-1}$ (due to the introduced azide function). It was subjected to DSC thermal analysis (Figure 2) showing $\mathrm{mp}$ $=55.1^{\circ} \mathrm{C}$ (lit. $53-54^{\circ} \mathrm{C}$ ), glass transition onset $T_{g}=87.7^{\circ} \mathrm{C}$, and $T_{d}=222.0^{\circ} \mathrm{C}$ (a much larger thermal stability range than compound 2). Compound $\mathbf{3}$ has oxygen balance $\boldsymbol{\Omega}=$ $-114.2 \%$, and a theoretical [20-23] detonation velocity $\mathbf{D}=$ $5088 \pm 102 \mathrm{~ms}^{-1}$.

The reaction of 3 with $\mathrm{HNO}_{3}$ produced compound 6 in excellent yield, a viscous liquid that remains as such at room temperature and is henceforth referred to as an RTEIL (room-temperature energetic ionic liquid) 6. This compound exhibited the characteristic ${ }^{1} \mathrm{H}$ NMR (broad singlet) signal at $9.08 \mathrm{ppm}$ due to the imidazolium proton. DSC analysis of $\mathbf{6}$ (Figure 2) shows a glass transition (onset) $T_{g}=81.6^{\circ} \mathrm{C}, T 1_{d}=$ $144.0^{\circ} \mathrm{C}$, and $T 2_{d}=225.0^{\circ} \mathrm{C}$. In a similar vein, the reaction of 3 with picric acid gave 7 , a white solid that was found to be the product of the cocrystallization of compound 3 and picric acid based on the DSC plot, which shows prominent endothermic peaks at $120.1^{\circ} \mathrm{C}$ and $135.0^{\circ} \mathrm{C}$ (Figure 2). Despite the indication of the presence of two distinct species by DSC, a certain degree of $\mathrm{H}$-bond association between 3 and picric acid in the solid mixture 7 is suggested by the fact that 3 has $\mathrm{mp}=55.1^{\circ} \mathrm{C}$, but the first endothermic peak appears in mixture 7 at a much higher temperature (Figure 2).

Apart from the potential uses of the compounds prepared herein as EMs, it is to be noted that compounds 2-6 would be worth screening for use as fungicides, antimicrobials, and enzyme inhibitors. A large number of metronidazole-derived compounds have been previously prepared by various groups seeking antimicrobial, antibacterial, or antiparasitic activity [29-32], as enzyme inhibitors [33, 34] and as candidates for prodrug bioavailability and cytotoxicity studies $[35,36]$. The structure of azides 3 and $\mathbf{6}$ in particular suggests their transformation into potentially useful pharmacologically active substances by exploiting the rich chemistry of their organic azide functionality. As described comprehensively by Bräse and Banert in his review [37], a great number of diverse nitrogen compounds can be synthesized by means of Click, Boyer, aza-Wittig, and Staudinger reactions, to name just a few of the current arsenal of transformations available for organic azides [38]. 


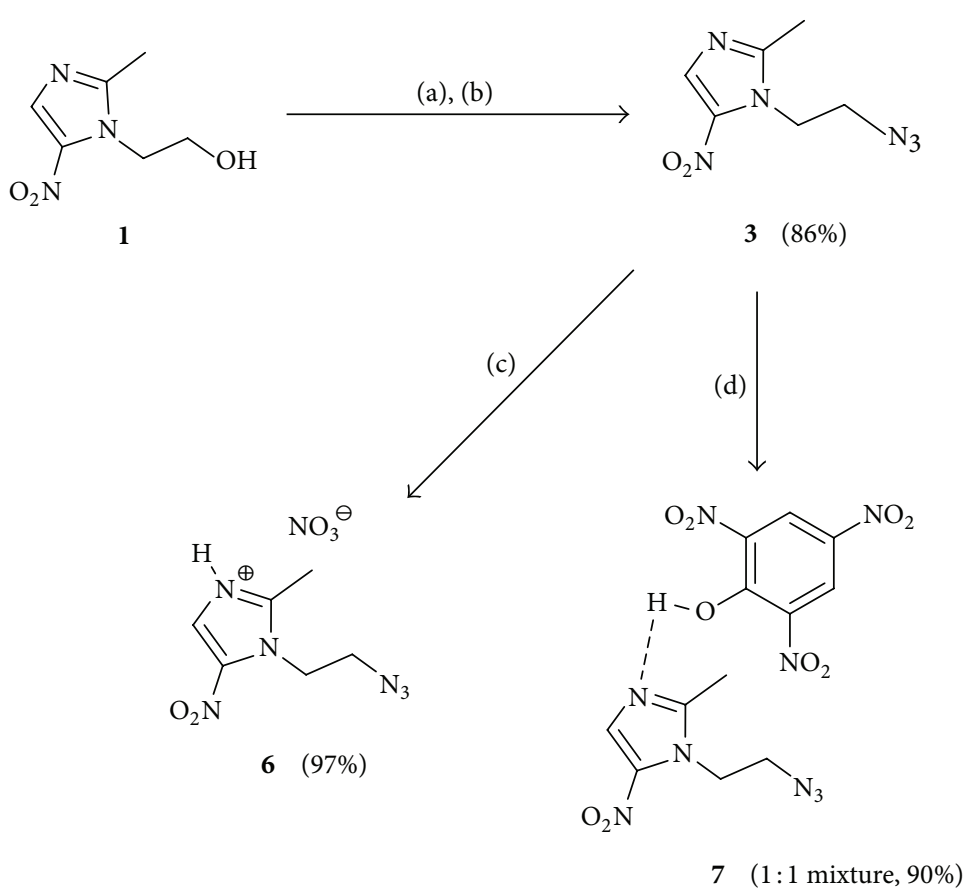

Scheme 2: Preparation of azide 3, RTEIL 6, and mixture 7. (a) $\mathrm{Ph}_{3} \mathrm{PBr}_{2}, \mathrm{CH}_{2} \mathrm{Cl}_{2}$; (b) $\mathrm{NaN}_{3}, \mathrm{DMF}$, and $60^{\circ} \mathrm{C}$; (c) $\mathrm{HNO}_{3}, \mathrm{CH}_{2} \mathrm{Cl}_{2}$, and $0^{\circ} \mathrm{C}$ and then r.t., $30 \mathrm{~min}$; and (d) picric acid, $\mathrm{Et}_{2} \mathrm{O}$.

\section{Conclusion}

Five new energetic compounds were prepared in a straightforward and efficient manner from the well-known and readily available antimicrobial metronidazole. Compounds 4-6 constitute ionic liquids ( 4 and $\mathbf{6}$ being proper RTEILs). Compound $\mathbf{6}$ may find practical uses as vehicle, additive, solvent, or otherwise mixture component for EM formulations. The instability of RTEIL 4 would preclude its use as a EM or EM additive. The nitrate ester 2 exhibits a moderate theoretical detonation velocity and may find application as a propellant when combined with a suitably strong oxidant $[39,40]$. From a pharmacological point of view, compounds $\mathbf{3}$ and $\mathbf{6}$ may be considered versatile precursors of a large array of useful compounds made available by known transformations of the azide functionality present in them, as discussed previously. Preliminary work in our laboratory has shown that azide 3 can be transformed into new compounds suitable for biological activity screening.

\section{Conflict of Interests}

The author declares that there is no conflict of interests regarding the publication of this paper.

\section{Acknowledgments}

Technical assistance by M.S. Julio C. Cortes (Nutek, S.A. de C.V.), M.S. Atilano Gutiérrez (UAM), and Q. Margarita Portilla (USAI-UNAM), is gratefully acknowledged. The author is grateful to Dr. Bernardo Frontana Uribe and MC.
Alejandra Núñez Pineda (CCIQS UAEM-UNAM) for graciously running DSC and TG analyses for compound 4. IR spectra and GCMS runs were courtesy of Nutek, S.A. de C.V., and are gratefully acknowledged. Otherwise the present work was entirely funded from the author's income.

\section{References}

[1] Q. Zhang and J. M. Shreeve, "Energetic ionic liquids as explosives and propellant fuels: a new journey of ionic liquid chemistry," Chemical Reviews, vol. 114, no. 20, pp. 10527-10574, 2014.

[2] A. R. Katritzky, H. Yang, D. Zhang et al., "Strategies toward the design of energetic ionic liquids: nitro- and nitrile-substituted $N, N^{\prime}$-dialkylimidazolium salts," New Journal of Chemistry, vol. 30, no. 3, pp. 349-358, 2006.

[3] E. Sebastiao, C. Cook, A. Hu, and M. Murugesu, "Recent developments in the field of energetic ionic liquids," Journal of Materials Chemistry A, vol. 2, no. 22, pp. 8153-8173, 2014.

[4] M. Smiglak, A. Metlen, and R. D. Rogers, "The second evolution of ionic liquids: from solvents and separations to advanced materials-energetic examples from the ionic liquid cookbook," Accounts of Chemical Research, vol. 40, no. 11, pp. 1182-1192, 2007.

[5] H. Bircher, "Explosive substances and their applications: an overview," Chimia, vol. 58, no. 6, pp. 355-362, 2004.

[6] F. Walkiewicz, K. Materna, A. Kropacz et al., "Multifunctional long-alkyl-chain quaternary ammonium azolate based ionic liquids," New Journal of Chemistry, vol. 34, no. 10, pp. 2281-2289, 2010.

[7] H. Gao and J. M. Shreeve, "Azole-based energetic salts," Chemical Reviews, vol. 111, no. 11, pp. 7377-7436, 2011. 
[8] L. Liu, Z. Li, C. Li, and S. Zhang, "Structural and thermal behavior of imidazolium N,N' ${ }^{\prime}$-dinitrourea," Journal of Molecular Structure, vol. 1015, pp. 67-73, 2012.

[9] M. Smiglak, C. C. Hines, W. M. Reichert et al., "Azolium azolates from reactions of neutral azoles with 1,3-dimethylimidazolium-2-carboxylate, 1,2,3-trimethyl-imidazolium hydrogen carbonate, and $\mathrm{N}, \mathrm{N}$-dimethyl-pyrrolidinium hydrogen carbonate," New Journal of Chemistry, vol. 37, no. 5, pp. 14611469, 2013.

[10] Y. Gao, C. Ye, B. Twamley, and J. M. Shreeve, "Energetic bicyclic azolium salts," Chemistry-A European Journal, vol. 12, no. 35, pp. 9010-9018, 2006.

[11] A. R. Katritzky, S. Singh, K. Kirichenko et al., "1-Butyl-3-methylimidazolium 3,5-dinitro-1,2,4-triazolate: a novel ionic liquid containing a rigid, planar energetic anion," Chemical Communications, no. 7, pp. 868-870, 2005.

[12] D. M. Drab, M. Smiglak, J. L. Shamshina et al., "Synthesis of $N$-cyanoalkyl-functionalized imidazolium nitrate and dicyanamide ionic liquids with a comparison of their thermal properties for energetic applications," New Journal of Chemistry, vol. 35, no. 8, pp. 1701-1717, 2011.

[13] R. P. Singh, R. D. Verma, D. T. Meshri, and J. M. Shreeve, "Energetic nitrogen-rich salts and ionic liquids," Angewandte Chemie-International Edition, vol. 45, no. 22, pp. 3584-3601, 2006.

[14] C. D. Freeman, N. E. Klutman, and K. C. Lamp, "Metronidazole. A therapeutic review and update," Drugs, vol. 54, no. 5, pp. 679708, 1997.

[15] J. E. Rosenblatt and R. S. Edson, "Metronidazole," Mayo Clinic Proceedings, vol. 62, no. 11, pp. 1013-1017, 1987.

[16] M. Smiglak, C. C. Hines, W. M. Reichert et al., "Synthesis, limitations, and thermal properties of energetically-substituted, protonated imidazolium picrate and nitrate salts and further comparison with their methylated analogs," New Journal of Chemistry, vol. 36, no. 3, pp. 702-722, 2012.

[17] H. J. Singh and U. Mukherjee, "Computational study of proton and methyl cation affinities of imidazole-based highly energetic ionic liquids," Journal of Molecular Modeling, vol. 17, no. 10, pp. 2687-2692, 2011.

[18] ACD/Labs Program, Advanced Chemistry Development, Inc., Toronto, ON, Canada, 2014, http://www.acdlabs.com.

[19] ACD/Labs Program, 2013, http://www.chemspider.com/ACDLabs.aspx.

[20] M. H. Keshavarz and H. R. Pouretedal, "Predicting the detonation velocity of CHNO explosives by a simple method," Propellants, Explosives, Pyrotechnics, vol. 30, no. 2, pp. 105-108, 2005.

[21] L. P. Rothstein and R. Petersen, "Predicting high explosive detonation velocities from their composition and structure," Propellants, Explosives, Pyrotechnics, vol. 4, no. 3, pp. 56-60, 1979.

[22] L. R. Rothstein, "Predicting high explosive detonation velocities from their composition and structure (II)," Propellants, Explosives, Pyrotechnics, vol. 6, pp. 91-93, 1981.

[23] R. L. J. Willer, "Calculation of the density and detonation properties of $\mathrm{C}, \mathrm{H}, \mathrm{N}, \mathrm{O}$ and $\mathrm{F}$ compounds: use in the design and synthesis of new energetic materials," Journal of the Mexican Chemical Society, vol. 53, no. 3, pp. 108-119, 2009.

[24] J. L. Anthony, S. N. V. K. Aki, E. J. Maginn, and J. F. Brennecke, "Feasibility of using ionic liquids for carbon dioxide capture," International Journal of Environmental Technology and Management, vol. 4, no. 1-2, pp. 105-115, 2004.
[25] E. D. Bates, R. D. Mayton, I. Ntai, and J. H. Davis Jr., " $\mathrm{CO}_{2}$ capture by a task-specific ionic liquid," Journal of the American Chemical Society, vol. 124, no. 6, pp. 926-927, 2002.

[26] C. W. Jones, " $\mathrm{CO}_{2}$ capture from dilute gases as a component of modern global carbon management," Annual Review of Chemical and Biomolecular Engineering, vol. 2, pp. 31-52, 2011.

[27] E. F. Levon, US Patent 3,962,274, (CA1067503A1), 1977.

[28] Compound 3 turned out to be pharmacologically inactive in 135 bioassay tests, https://pubchem.ncbi.nlm.nih.gov/compound/ NSC265263.

[29] H. A. Saadeh, I. M. Mosleh, A. G. Al-Bakri, and M. S. Mubarak, "Synthesis and antimicrobial activity of new 1,2,4-triazole3-thiol metronidazole derivatives," Monatshefte für ChemieChemical Monthly, vol. 141, no. 4, pp. 471-478, 2010.

[30] A. J. K. Atia, "Synthesis and antibacterial activities of new metronidazole and imidazole derivatives," Molecules, vol. 14, no. 7, pp. 2431-2446, 2009.

[31] S. Khabnadideh, Z. Rezaei, A. K. Nezhad, M. H. Motazedian, and M. Eskandari, "Synthesis of metronidazole derivatives as antigiardiasis agents," DARU Journal of Pharmaceutical Sciences, vol. 15, no. 1, pp. 17-20, 2007.

[32] K. Bowden and J. Izadi, "Multifunctional derivatives of metronidazole," Il Farmaco, vol. 53, no. 1, pp. 58-61, 1998.

[33] W.-J. Mao, P.-C. Lv, L. Shi, H.-Q. Li, and H.-L. Zhu, "Synthesis, molecular docking and biological evaluation of metronidazole derivatives as potent Helicobacter pylori urease inhibitors," Bioorganic \& Medicinal Chemistry, vol. 17, no. 21, pp. 7531-7536, 2009.

[34] Y.-L. Sang, Y.-T. Duan, H.-Y. Qiu et al., "Design, synthesis, biological evaluation and molecular docking of novel metronidazole derivatives as selective and potent JAK3 inhibitors," RSC Advances, vol. 4, no. 32, pp. 16694-16704, 2014.

[35] N. M. Mahfouz and M. A. Hassan, "Synthesis, chemical and enzymatic hydrolysis, and bioavailability evaluation in rabbits of metronidazole amino acid ester prodrugs with enhanced water solubility," Journal of Pharmacy and Pharmacology, vol. 53, no. 6, pp. 841-848, 2001.

[36] K. Abdi, A. Khalaj, S. N. Ostad, N. Lamei, and M. R. Khoshayand, "Synthesis, in vitro aerobic and hypoxic cytotoxicity and radiosensitizing activity of novel metronidazole tethered 5-fluorouracil," DARU-Journal of Pharmaceutical Sciences, vol. 21, no. 1, article 76, 2013.

[37] S. Bräse, C. Gil, K. Knepper, and V. Zimmermann, "Organic azides: an exploding diversity of a unique class of compounds," Angewandte Chemie - International Edition, vol. 44, no. 33, pp. 5188-5240, 2005.

[38] S. Bräse and K. Banert, Organic Azides. Synthesis and Applications, Wiley, 2010.

[39] J. L. Shamshina, M. Smiglak, D. M. Drab et al., "Catalytic ignition of ionic liquids for propellant applications," Chemical Communications, vol. 46, no. 47, pp. 8965-8967, 2010.

[40] S. Schneider, T. Hawkins, M. Rosander, J. Mills, G. Vaghjiani, and S. Chambreau, "Liquid azide salts and their reactions with common oxidizers IRFNA and $\mathrm{N}_{2} \mathrm{O}_{4}$," Inorganic Chemistry, vol. 47, no. 13, pp. 6082-6089, 2008. 

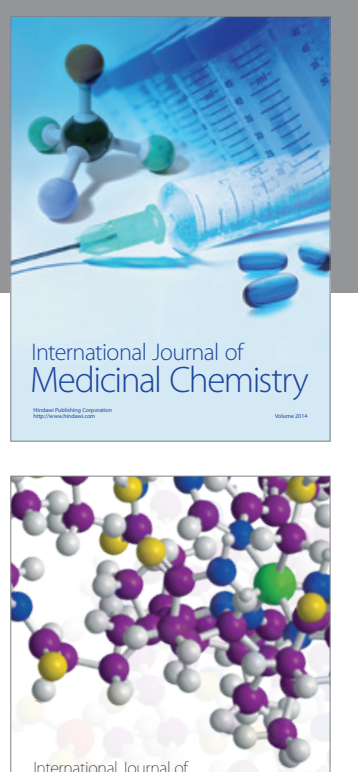

Carbohydrate Chemistry

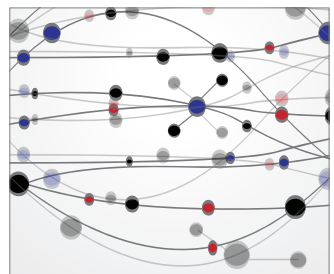

The Scientific World Journal
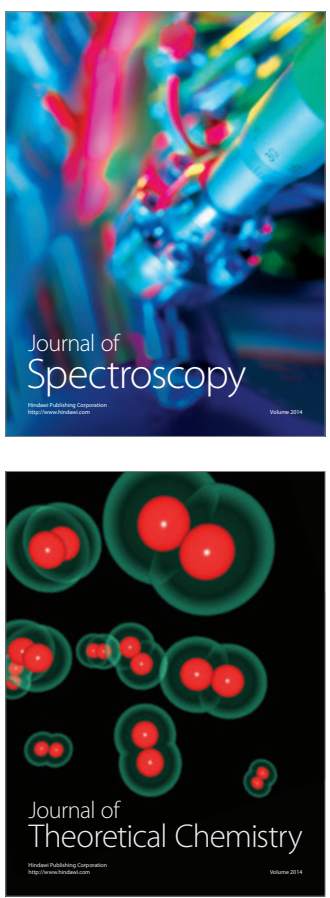
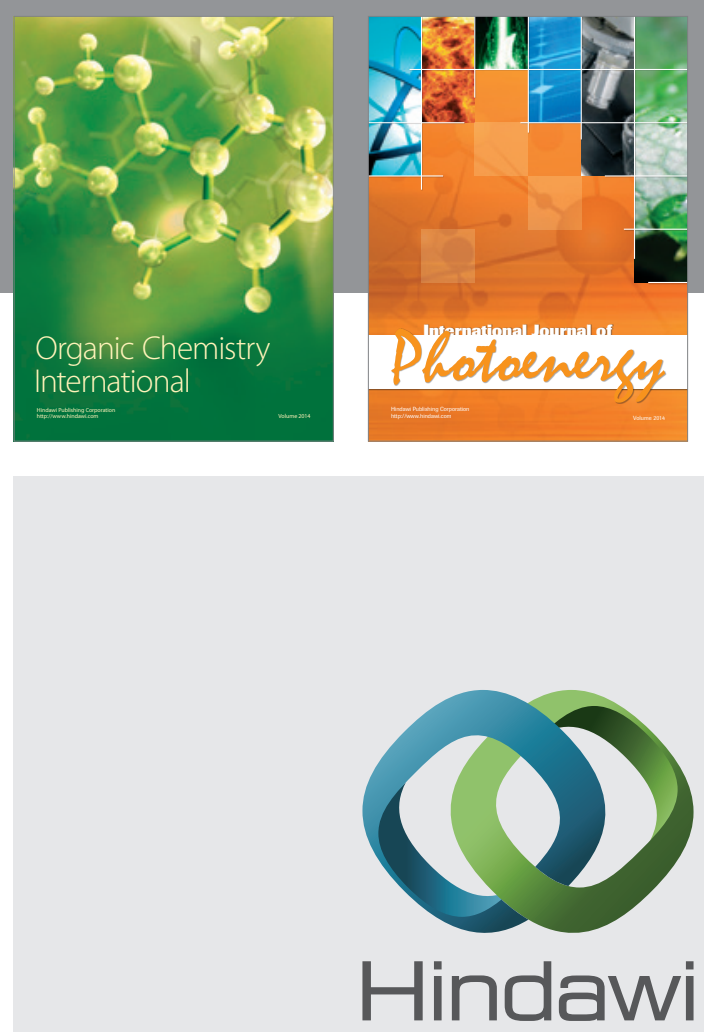

Submit your manuscripts at

http://www.hindawi.com

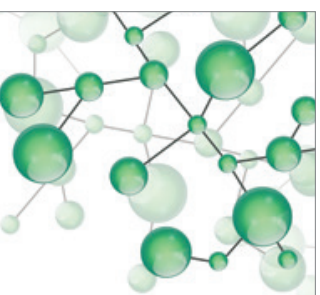

International Journal of

Inorganic Chemistry

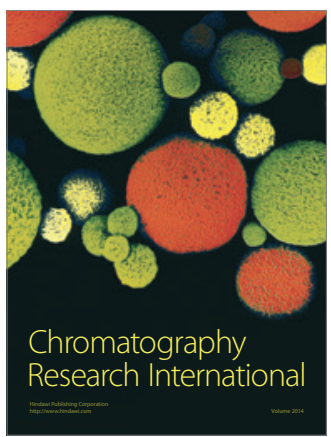

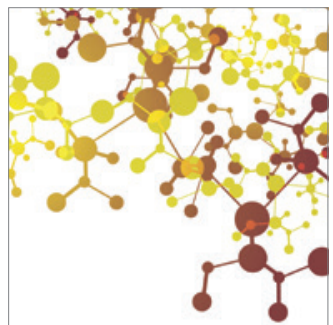

Applied Chemistry
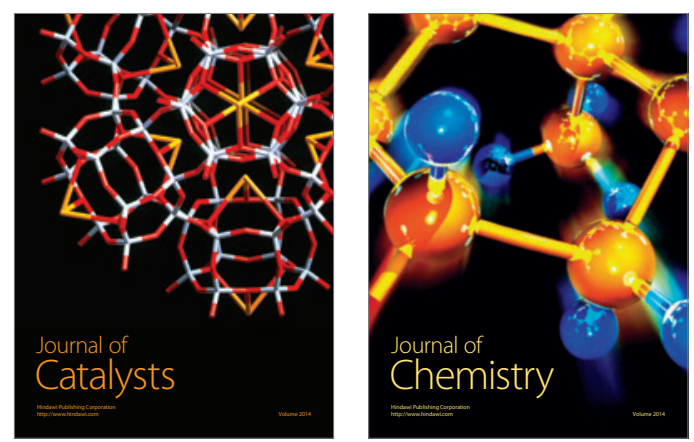
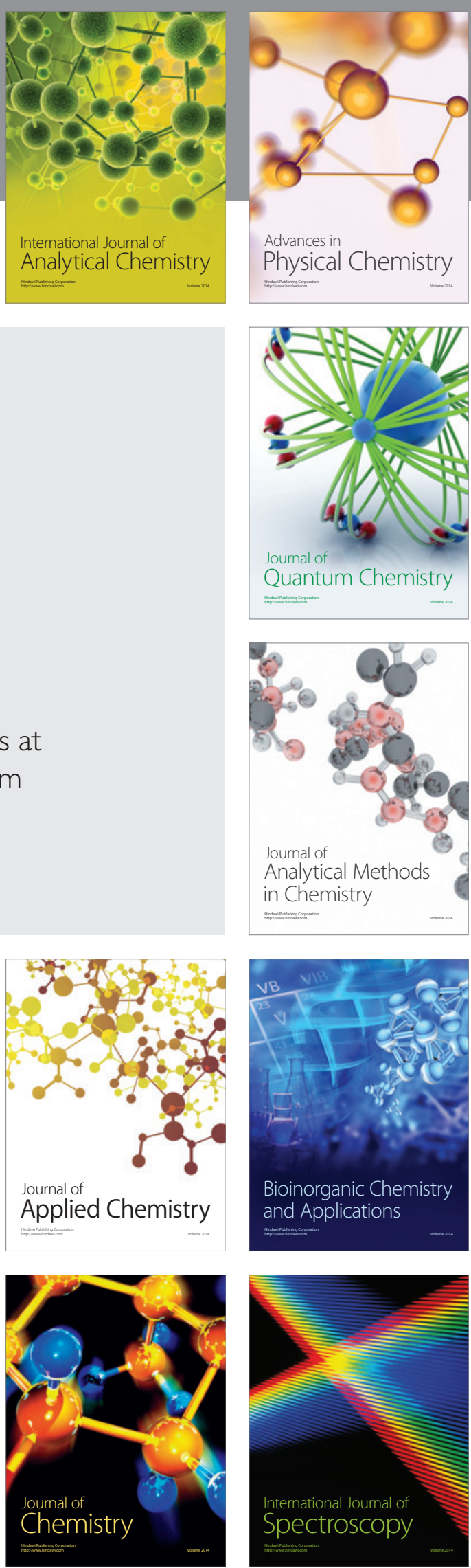